LAW RENCE LIVERMORE N A T IO N A L LABORATORY

\section{Electrochemical Machining of Metal Plates}

J. F. Cooper, M. C. Evans

March 14, 2005 
This document was prepared as an account of work sponsored by an agency of the United States Government. Neither the United States Government nor the University of California nor any of their employees, makes any warranty, express or implied, or assumes any legal liability or responsibility for the accuracy, completeness, or usefulness of any information, apparatus, product, or process disclosed, or represents that its use would not infringe privately owned rights. Reference herein to any specific commercial product, process, or service by trade name, trademark, manufacturer, or otherwise, does not necessarily constitute or imply its endorsement, recommendation, or favoring by the United States Government or the University of California. The views and opinions of authors expressed herein do not necessarily state or reflect those of the United States Government or the University of California, and shall not be used for advertising or product endorsement purposes.

This work was performed under the auspices of the U.S. Department of Energy by University of California, Lawrence Livermore National Laboratory under Contract W-7405-Eng-48. 


\title{
Electrochemical Machining of Metal Plates
}

\author{
John F. Cooper and Mark C. Evans \\ Chemistry and Materials Science Directorate \\ Lawrence Livermore National Laboratory, L-352, Livermore CA 94550 \\ Tel. (925) 423-6649, Fax (925) 422-0049, Email cooper3@LLNL.gov
}

February 17, 2005 


\section{Table of Contents}

Electrochemical Machining of Metal Plates............................................................... 3

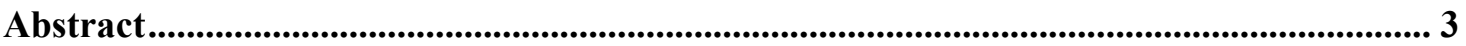

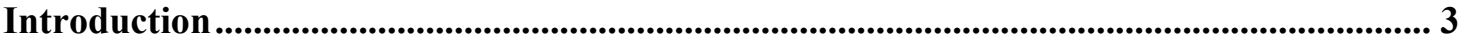

Technical Basis of Electrochemical Machining ............................................................................... 4

Experimental Basis of Electrochemical Machining ...................................................................5 5

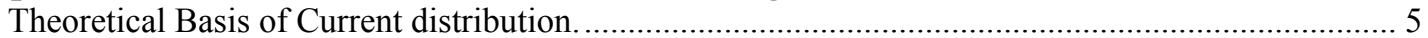

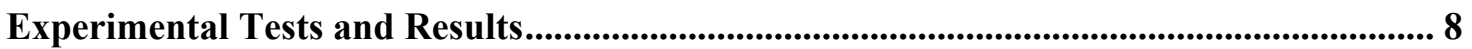

1. Stationary cathode

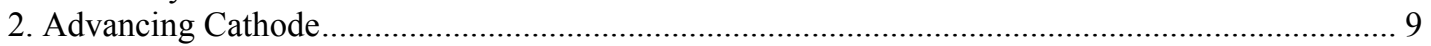

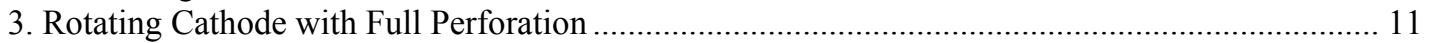

4. Rotating Cathode, Full Perforation and Increased Efficiency ....................................................... 12

5. Rotating Cathode, Perforation Completed using a Utility Knife; Temperature Profiles.................. 13

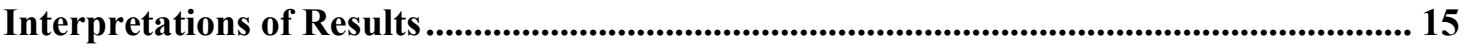

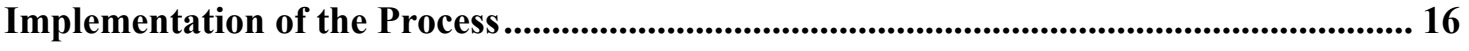

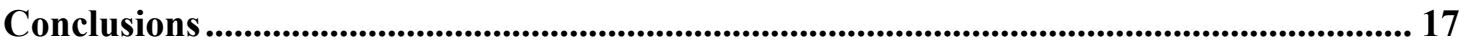

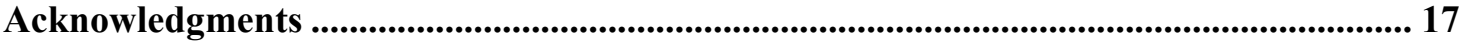

Appendix A. Temperature Profiles During Electrochemical Machining ............................ 18 


\title{
Electrochemical Machining of Metal Plates
}

\author{
John F. Cooper and Mark Evans \\ Chemistry and Materials Science Directorate \\ Lawrence Livermore National Laboratory, L-352, Livermore CA 94550 \\ Tel. (925) 423-6649, Fax (925) 422-0049, Email cooper3@LLNL.gov
}

\begin{abstract}
Electrochemical machining (ECM) with concentrated sodium chlorate electrolyte was used to rapidly cut a circular groove $(13 \mathrm{~cm}$ diameter, $0.2 \mathrm{~cm}$ wide) through a $0.15 \mathrm{~cm}$ thick sheet of steel - thus opening a 5-inch porthole in as little as 10 minutes. The most favorable operating conditions were: $\mathrm{T}=22{ }^{\circ} \mathrm{C}$; chlorate concentration $600 \mathrm{~g}$ $\mathrm{NaClO}_{3} /$ liter-solution; electric power of $100 \mathrm{~A}$ at $10 \mathrm{~V}$; and flow of $0.5 \mathrm{l} / \mathrm{s}$ at a pressure drop of $10 \mathrm{kPa}(1.5 \mathrm{psi})$. The porthole may be removed entirely by electrochemical means, or the electrochemical dissolution may continue until only thin membrane remains that is subsequently cut with a utility knife. An array of thermocouples was used to track temperature in the flowing solution and in the trough being machined; the maximum increase in temperature in the trough was $5{ }^{\circ} \mathrm{C}$ over that of the flowing electrolyte which increased in temperature by $19^{\circ} \mathrm{C}$ because of power dissipation. ECM is shown feasible for rapid perforation of plates of ferrous and non-ferrous metals using portable equipment and commercial batteries. The technique can be extended to cut perforations of arbitrary shape through non-planar surfaces using a deformable ring cathode. Analysis of the power requirements for electrolyte flow and ECM indicate a total system weight of less than $45 \mathrm{~kg}(100 \mathrm{lb})$ using a commercial NiMH battery. The technique is recommended for reduction to practice and demonstration on full scale as an engineering prototype.
\end{abstract}

\section{Introduction}

The objective of this work is to develop a silent, low-impact, low vibration, low temperature technique to cut a 5-inch diameter access hole through sheet metal (nominal thickness, $1.5 \mathrm{~mm}$ ) in 10 minutes or less. The equipment for doing so must be selfcontained, lightweight (man portable, below $100 \mathrm{lb}$ ) and readily transportable. The metal may be mild steel, stainless steel, tool steel or non-ferrous metals such as brass, copper, aluminum or titanium, etc. The technique must accommodate plate thickness of $1 \mathrm{~cm}$.

Electrochemical machining was chosen for this application. Electrochemical machining is a technique whereby metals are cut, shaped and polished by the passage of anodic current through the metal work piece (the anode, grounded), across an electrolyte gap, and into a second metal electrode (the cathode). ${ }^{1}$ The rate of cutting is independent of the hardness of the metal, and to a first approximation is independent of the identity of the metal or alloy. The cut replicates the geometry of the cathode. The process is shown schematically in Figure 1.

\footnotetext{
${ }^{1}$ Electrochemical Machining (ed. A. E. de Barr and D. A. Oliver, American Elsevier, 1968.)
} 


\section{Technical Basis of Electrochemical Machining}

The rate of the cut is determined by the current density, by the equivalent weight and density of the metal, and by losses due to side reactions. From Faraday's law, the rate of the cutting process may be expressed:

$$
\mathrm{dS} / \mathrm{dt}=\eta_{\mathrm{c}}(\mathrm{i} / \mathrm{nF})\left(\mathrm{M}_{\mathrm{w}} / \rho\right)
$$

Here $\mathrm{S}$ is the depth of the cut, $\mathrm{I}$ is the current density $\left(\mathrm{A} / \mathrm{cm}^{2}\right), \mathrm{n}$ is the valence of the metal (equivalents/mole), $\mathrm{F}$ is the Faraday constant ( 96500 coulombs/equivalent), $\mathrm{M}_{\mathrm{w}}$ is the atomic weight of the metal, and $\rho$ is the density of the metal. The term $\eta_{\mathrm{c}}$ is the current efficiency of the anodic current - the fraction of the charge passed that is effective in dissolving the metal assuming a valence, $n$. Current efficiencies of less than unity typically result from the evolution of oxygen at the anode along with metal dissolution; efficiencies of greater than unity are also possible if the anodic process results in the undermining and removal of crystal grains. Assuming $100 \%$ current efficiency, and for the properties of mild steel $\left(\mathrm{n}=3, \mathrm{M}_{\mathrm{w}}=55.85 \mathrm{~g} / \mathrm{mol}, \rho=7.86 \mathrm{~g} / \mathrm{cm}^{3}\right)$, the cut rate is then 0.25 micrometers per second at a current density of $1 \mathrm{~A} / \mathrm{cm}^{2}$. Thus, to cut a plate $1.5 \mathrm{~mm}$ thick in 10 minutes requires a current density of $10.2 \mathrm{~A} / \mathrm{cm}^{2}$. For most metals, the rate coefficient $\left(\mathrm{M}_{\mathrm{w}} / \rho \mathrm{\rho F}\right)$ in equation 1 has a narrow range of values between 0.25 and $0.5 \mu \mathrm{m} / \mathrm{s}$ for $\mathrm{Fe}, \mathrm{Ni}, \mathrm{Cu}, \mathrm{Zn}, \mathrm{Al}$, Ti and their alloys.

In industrial electrochemical machining, the current is applied at densities of 1$100 \mathrm{~A} / \mathrm{cm}^{2}$. At such elevated rates, the electrolyte must be forced between the electrodes at a high rate to remove heat, reaction products and the gasses evolved at the cathode (hydrogen). The cathode reaction involves chiefly the electrochemical reduction of water:

$$
2 \mathrm{H}_{2} \mathrm{O}+2 \mathrm{e}^{-}=\mathrm{H}_{2}+2 \mathrm{OH}^{-}
$$

The hydrogen is harmlessly entrained as a fine dispersion of bubbles into the electrolyte and exhausted to the atmosphere in an open separation tank. In our system described below, the steady state concentration of hydrogen in the flow is $2 \%$ by volume.

The anodic reaction can be assumed to be dissolution of iron to $\mathrm{Fe}(\mathrm{III})$ and precipitation by water to from $\mathrm{Fe}(\mathrm{OH})_{3}$ :

$$
\mathrm{Fe}+3 \mathrm{H}_{2} \mathrm{O}=\mathrm{Fe}(\mathrm{OH})_{3}+3 \mathrm{H}^{+}+3 \mathrm{e}^{-}
$$

The balanced net reaction (summing equations 2 and 3 ) may be represented:

$$
2 \mathrm{Fe}+6 \mathrm{H}_{2} \mathrm{O}=2 \mathrm{Fe}(\mathrm{OH})_{3}+3 \mathrm{H}_{2}
$$

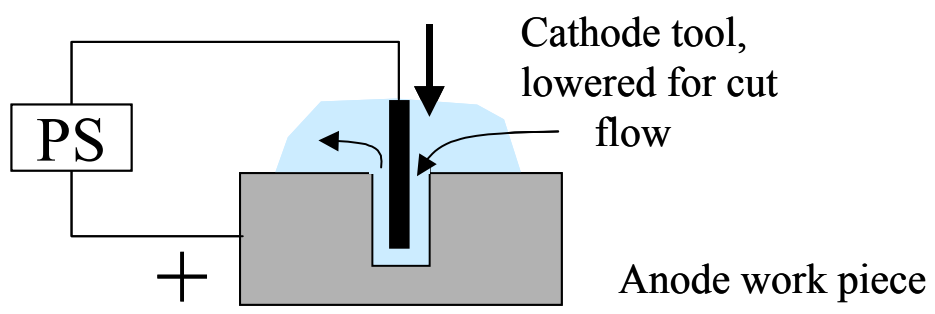

Fig. 1. The cutting of a rectangular channel uses a narrow rectangular cathode, insulated on the vertical surfaces, with a constant current applied by a power supply, PS. If the cathode is in the shape of a narrow ring of $13 \mathrm{~cm}$ diameter, the plate may be perforated for removal of a $13 \mathrm{~cm}$ diameter disk. 


\section{Experimental Basis of Electrochemical Machining}

Theoretical Basis of Current distribution.

The current flow and the shape of the cut is determined to a good approximation by solution of Laplace's equation $\left(\nabla^{2} \Phi=0\right)$, between two potential surfaces. This current distribution is independent of electrolyte conductivity and is called "primary" current distribution. Current distribution will be controlled by the dimensions of the smaller electrode, at which surface the lines of current flow are close together. The first correction on this model (called "secondary" current distribution) includes boundary conditions that reflect the voltage drop across the surface of the electrodes resulting from kinetic resistance of the electrochemical reactions. These boundary conditions tend to make the current flow more uniformly across the larger electrode than might be predicted by primary current distribution. For a general discussion of potential and current distribution in electrochemical systems, see Newman. ${ }^{2}$

The chemical properties of the electrolyte may benefit current distribution. A localization of current flow to smallest dimensions of the anode is desirable to minimize the time required for cutting at a fixed current. Certain oxidizing electrolytes (such as sodium chlorate, the one used in this work) achieve this by chemically oxidizing the surface of many metals in the vicinity of the cut, resulting in local passivation. This passivation tends to concentrate the flow of current to the part of the work piece directly opposite the cathode, where the fields are strong enough to overcome the passivation. Thus the cutting is focused to form a narrow trench.

Of particular interest is the research leading to the use of sodium chlorate electrolytes for applications in automotive manufacturing. LaBoda and McMillan ${ }^{3}$ compared chlorate, chloride and nitrate electrolytes in the high rate cutting of various steels. The throwing power (or focusing of cutting action) was maximized with the use of the chlorate, because of the formation of distinct active, passive and transpassive regimes having distinct electrode potentials and spatial distribution relative to the cathode.

\section{Experimental System}

The experimental system (Fig. 2 through 5) is designed to cut plates of thickness between 0.1 and $0.3 \mathrm{~cm}(0.040-0.12 \mathrm{inch})$ and held between a polycarbonate cell and an electrically grounded base plate made of brass. The electrolyte is circulated between the cell and a holding tank. Baffles aid separation of electrolyte from entrained gas. The cathode assembly (Fig. 3) may be advanced towards the anode by rotation in a threaded bearing (30 pitch). The cell may be operated either in stationary mode (with a $0.5 \mathrm{~mm}$ gap), or advanced to maintain a constant inter-electrode gap. Photographs of the experimental cell and system are shown in Fig. 4-5.

The power supply is an Electronic Measurements Inc. power supply (30 V at 200 A). Voltage measurements were made using calibrated hand held voltmeters (Fluke Model 77 Multimeter). The centrifugal pump provides a constant flow of $0.541 / \mathrm{s}(8.5$ gpm), which is determined primarily by the hydraulic resistances of the $3 / 4$ "connecting

\footnotetext{
${ }^{2}$ John S. Newman, Electrochemical Systems (Prentice-Hall, Inc. Englewood Cliffs NJ 1973).

${ }^{3}$ M. A. LaBoda and M. L. McMillan, A New Electrolyte for Electrochemical Machining, Electrochem.

Techol. 5, 340 (1967).
} 
tubing and not by the inter-electrode gap. Flow is regulated by valves on the main and bypass circuits, and measured by an in-line flow meter (King Instruments, 0-20 gpm). The centrifugal water pump (Motor Applications Corporation) is rated at 1/8 HP (94 W) and $50 \mathrm{rpm}$. Its capacity far exceeds requirements of this cell.

The electrolyte used was Baker Reagent sodium chlorate. The solutions were prepared by dissolving the salt in deionized water to make concentrations up to $600 \mathrm{~g}$ $\mathrm{NaClO}_{3}$ /liter-solution (5.63 M).

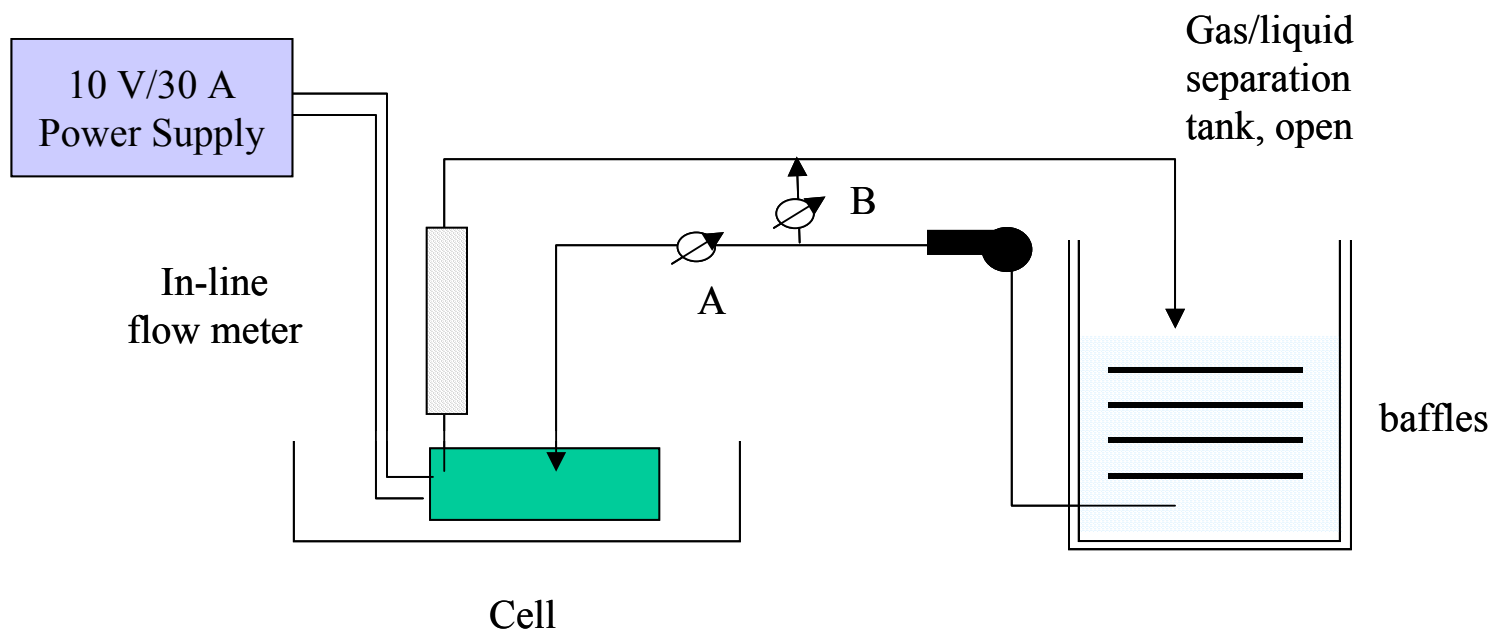

Fig. 2. This schematic shows the flow system used in cutting of metal disks by ECM.

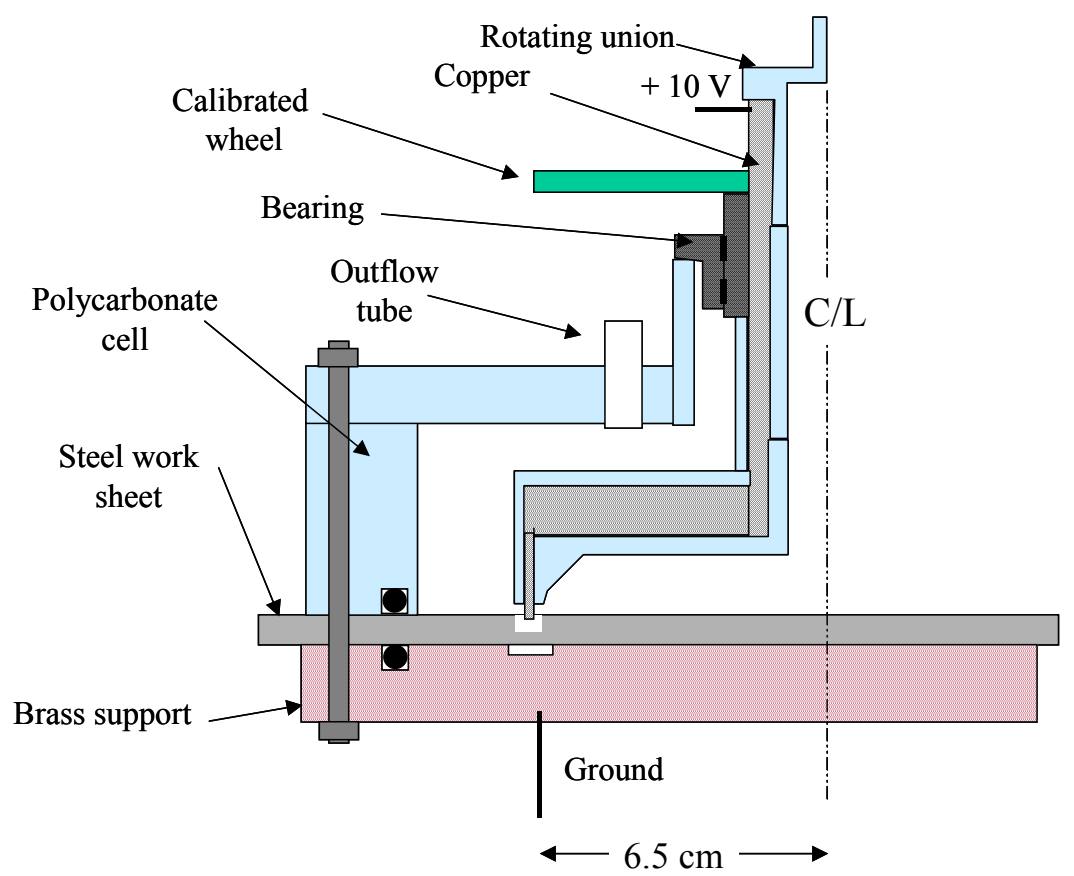

Fig. 3. The cylindrical, axisymmetric cell is shown in cross-section. The ring cathode ( 0.5 $\mathrm{mm}$ wide, $3 \mathrm{~mm}$ long, $13 \mathrm{~cm}$ diameter) is insulated on the vertical surfaces. 


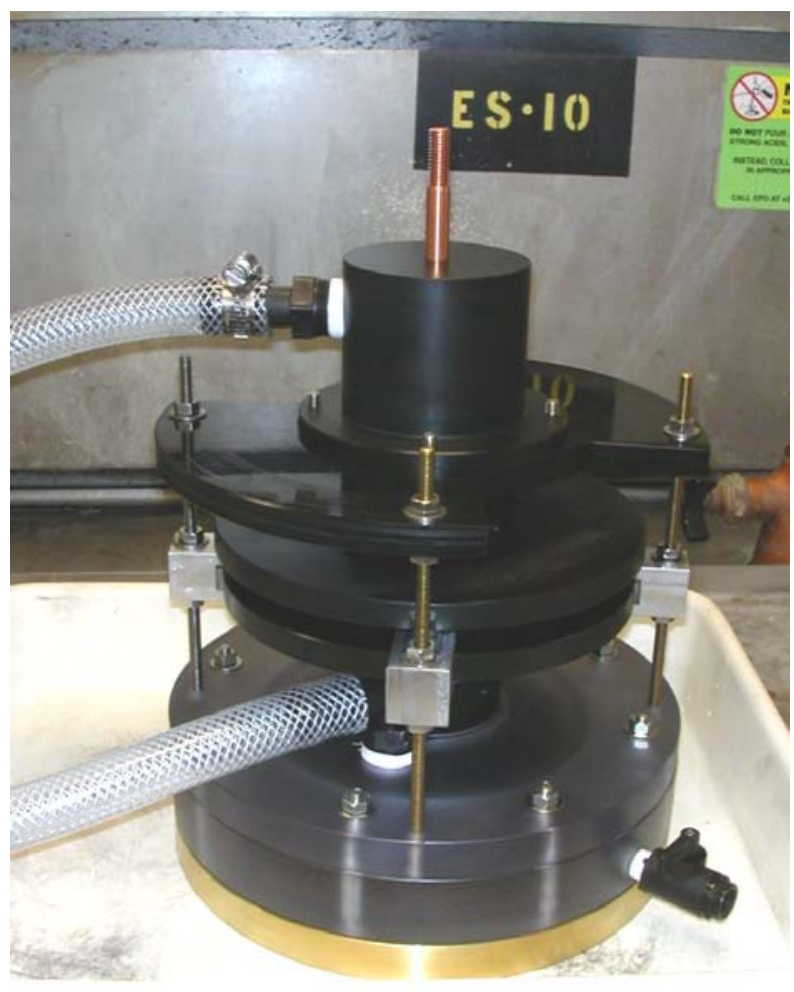

Fig. 4. The photograph shows the experimental cell.

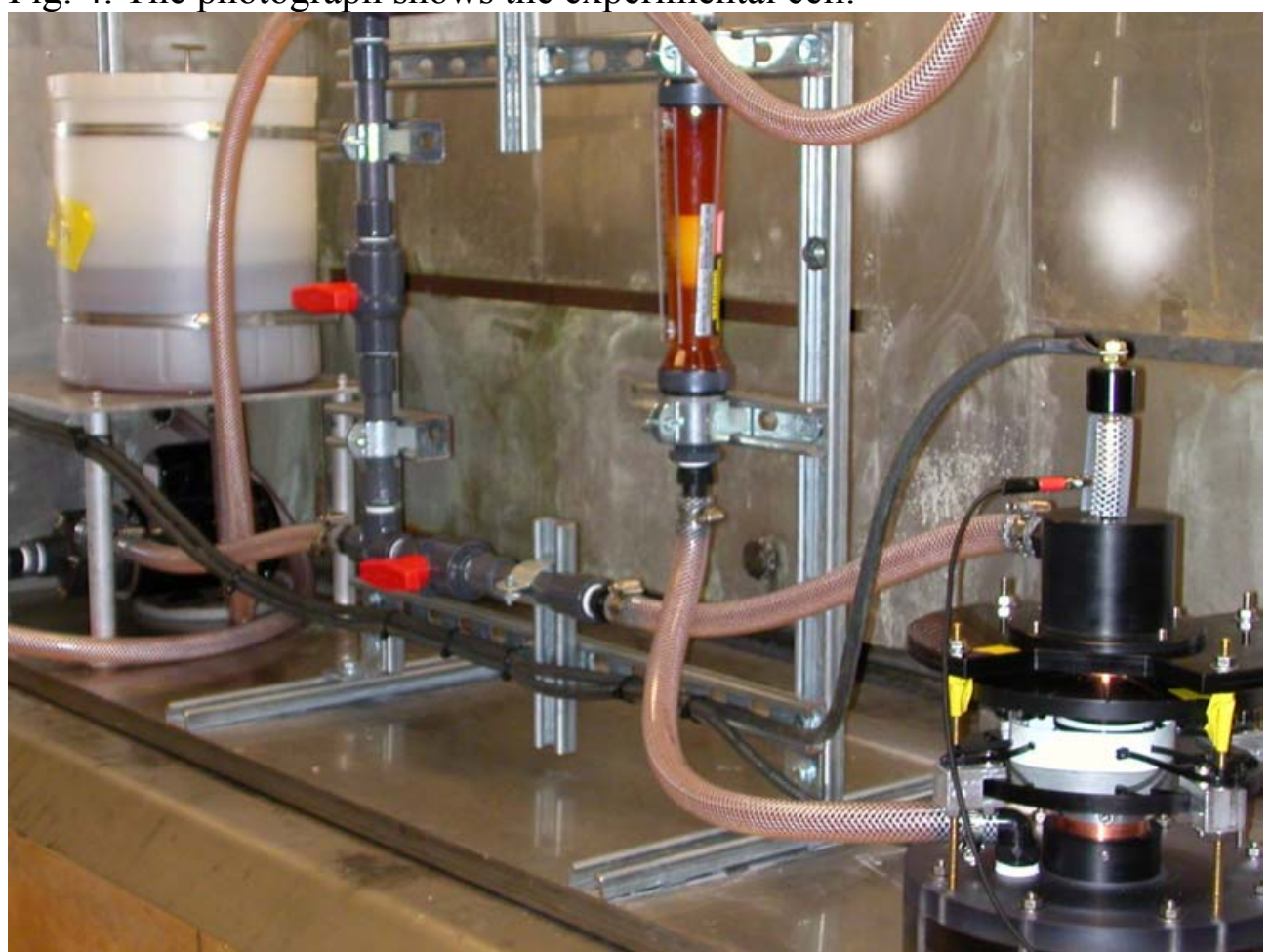

Fig. 5. The experimental system is shown. Cell, connecting tubing and storage tanks are made of a non-corrosive plastic. A stainless steel baffle is used within the storage tank to separate gas from liquid and stabilized the flow. 


\section{Experimental Tests and Results}

Five initial experiments were conducted on mild steel plate of thickness $1.5 \mathrm{~mm}$ (0.0625 inches). In the first, the cathode tool was not rotated nor advanced. In the second, the cathode was rotated and advanced just short of full perforation. In the third, a disk was cut free by electrochemical means. In the fourth experiment, process parameters were adjusted to increase rate, resulting in complete removal of an intact disk in less 11 minutes. In the final (fifth) experiment, the system was diagnosed with an array of thermocouples in the bulk solution and in the machined trough; following near perforation of the plate, the disk was removed by cutting through the residual membrane with a utility knife.

\section{$\underline{1 . S t a t i o n a r y ~ c a t h o d e ~}$}

A polarization curve was developed with the cathode positioned $0.42 \mathrm{~mm}$ away from the anode (Fig. 6). The cathode was re-positioned $0.16 \mathrm{~mm}$ above the surface, and current of 50 A was sustained for 6.0 minutes. Figure 7 shows the cross-section of the plate after a total of $21 \times 10^{3}$ coulombs was passed through the cell for a total of 7 minutes. This quantity charge should result in a removal of $4.1 \mathrm{~g}\left(0.51 \mathrm{~cm}^{3}\right)$ of iron or an average depth of $0.64 \mathrm{~cm}$ (0.08 inches) assuming cut width of $2 \mathrm{~mm}$ and diameter of 12.7 $\mathrm{cm}$ (5 in). The depth of the cut varied with azimuth from $0.3 \mathrm{~mm}$ to $0.7 \mathrm{~mm}$, with an average depth of $0.5 \mathrm{~mm}$. The average depth of $0.5 \mathrm{~mm}$ suggests that the process was $80 \%$ efficient according to equation (4).

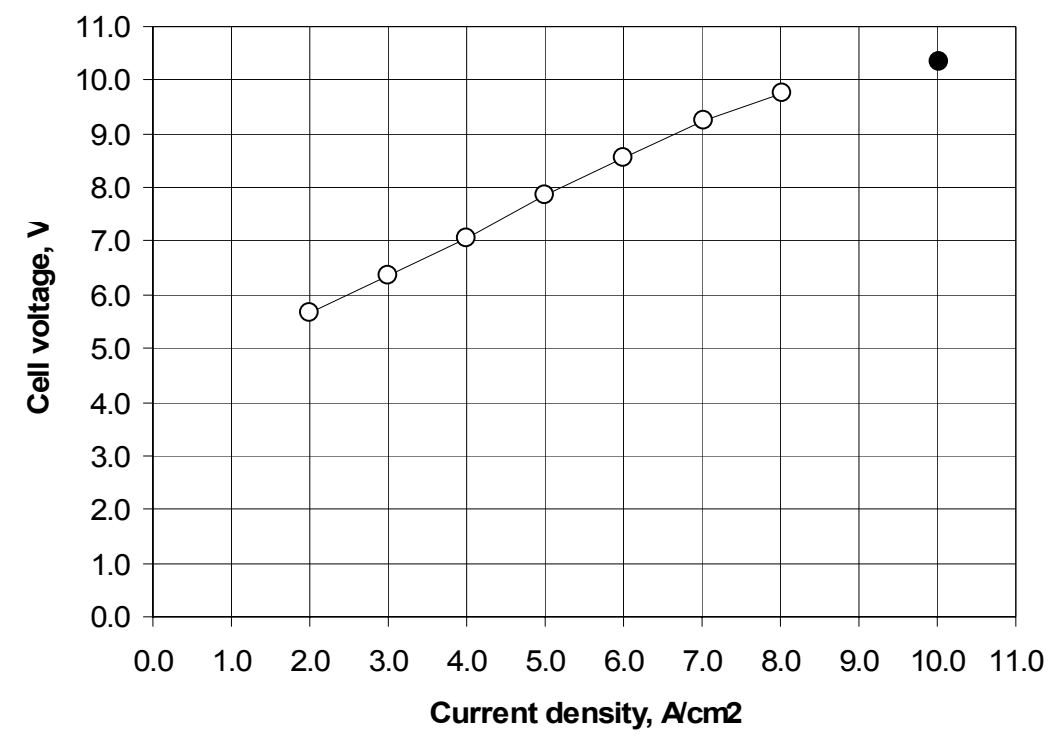

Fig. 6. Cell voltage increases with applied current. Total current is normalized to the 5.0 $\mathrm{cm}^{2}$ area of the cathode. Open data points: $0.42 \mathrm{~mm}$ electrode gap; closed point, $0.16 \mathrm{~mm}$ initial electrode gap. 


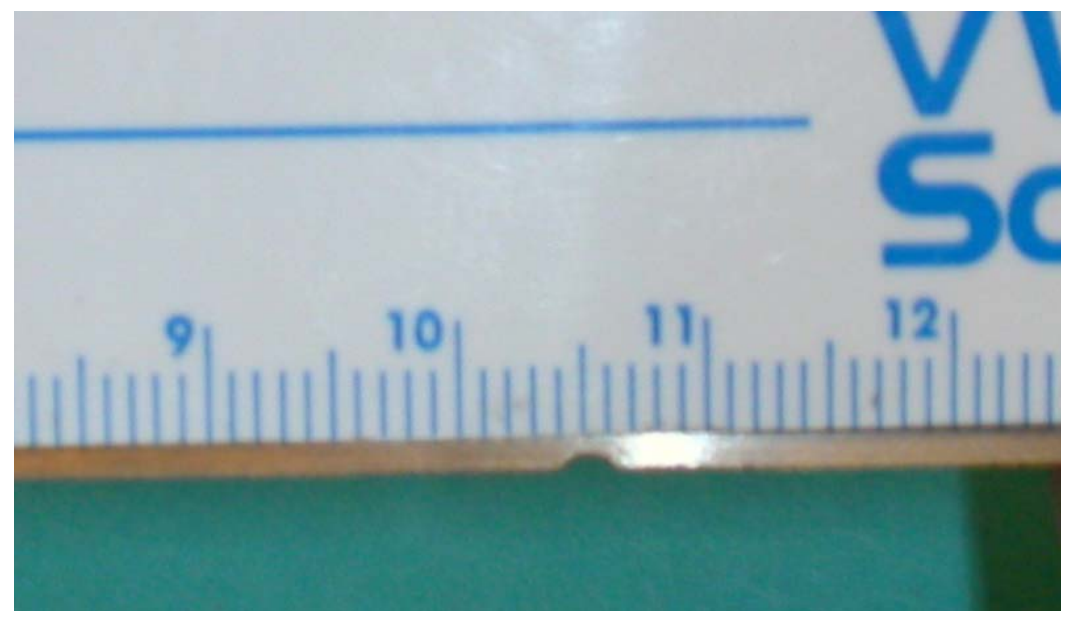

Fig. 7. Cross-section of cut after $21 \times 10^{3}$ coulombs passed during experiment with stationary (non-rotating) cathode $(0.16 \mathrm{~mm}$ initial gap) for 7 minutes.

\section{Advancing Cathode}

In this experiment, the cathode was rotated and advanced through the sheet metal in synchronization with the cut. Two rotations advanced the cathode a distance of 0.15 $\mathrm{cm}$ (0.060 inches). This resulted in a nearly complete perforation of the plate.

The polarization curve is shown in Fig. 8. Power ranged from a maximum of 550 $\mathrm{W}$ to a minimum of $300 \mathrm{~W}$ towards end of the experiment. The drop in power and voltage during the cutting operation is attributable to the detachment of the lacquer insulation from the vertical surfaces of the cathode that resulted in a larger cross-sectional area of the cut and a lowering of resistance. The increase in temperature of the electrolyte (resulting from power dissipation into the flowing electrolyte) also decreased power consumption.

The cross section photograph (Fig. 9) shows a pronounced "V" shaped cut. This shape results from the current flow from the un-insulated cathode surface laterally to the edges of the trough as the trough deepened. Figure 10 plots the azimuth distribution in trough depth. The depth ranged from $60 \%$ of the plate thickness up to nearly $100 \%$ of thickness. Upon disassembly, it was found that the lacquer insulation partially detached from the cathode and blocked part of the work piece surface, leading to the non-uniform depth of the trough.

The temperature of the 10 liters of electrolyte increased by $12{ }^{\circ} \mathrm{C}$ (from $18{ }^{\circ} \mathrm{C}$ to $30^{\circ} \mathrm{C}$ ) during the rotating cathode experiment. This compares well with the energy dissipation $(150 \mathrm{Wh} ; 540 \mathrm{k} \mathrm{J})$ that predicts an adiabatic temperature increase of $12.9^{\circ} \mathrm{C}$. The $\mathrm{pH}$ of the electrolyte was unaltered by the run, remaining at 6.9. 


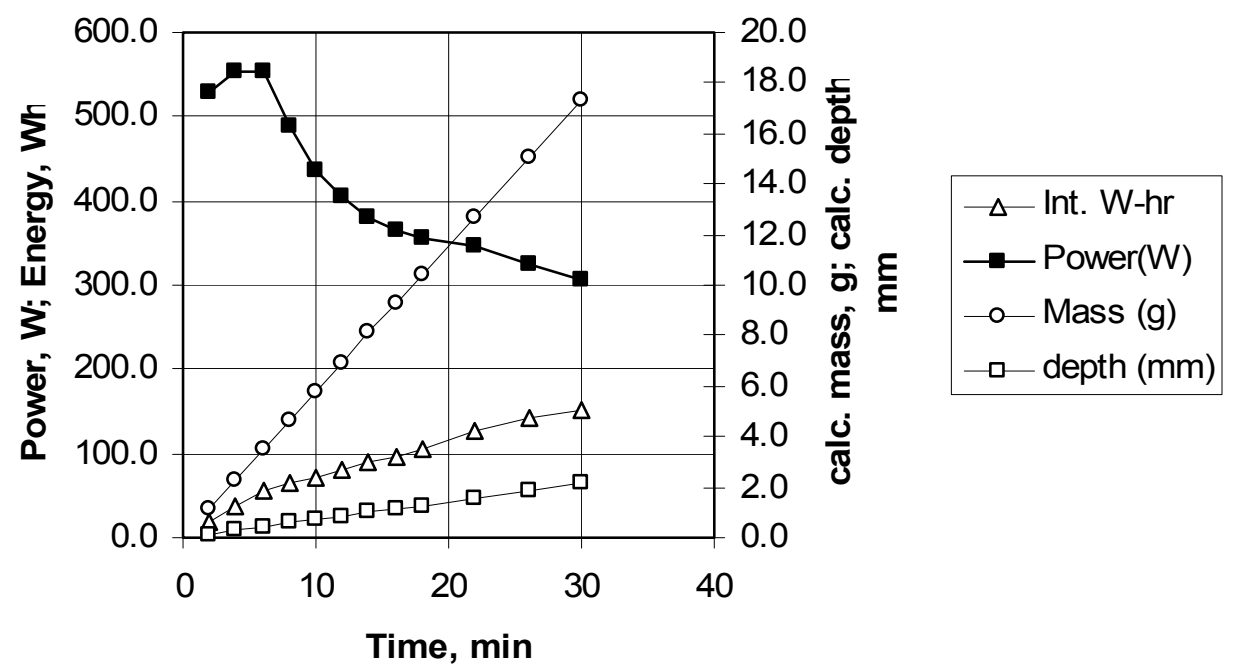

Fig.8. Polarization of the cell with step-wise rotation of the cathode to advance the cathode by $0.12 \mathrm{~mm} / \mathrm{step}$; total advance was $1.68 \mathrm{~mm}$. The current was fixed at 50 $\mathrm{A}$, and power ranged from $300-550 \mathrm{~W}$ (6 to $11 \mathrm{~V}$ at $50 \mathrm{~A})$. The total integrated energy was $150 \mathrm{Wh}$, while the calculated mass removed $(17 \mathrm{~g})$ well exceeded the measured $(7.5 \mathrm{~g})$ due to side reactions associated with the evolution of oxygen.

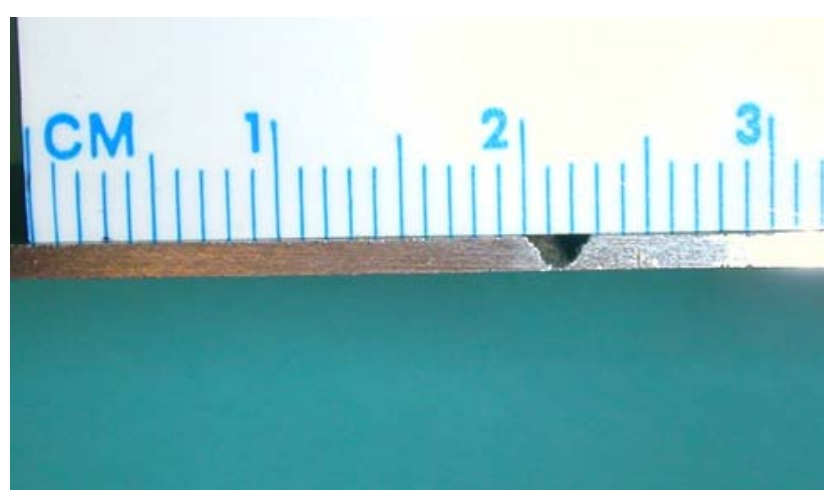

Fig.9. The cross-section of the trough shows a "V" shape resulting from the increased current flow from the vertical surfaces of the cathode following from the nonuniform detachment or removal of the insulating lacquer on the cathode. 


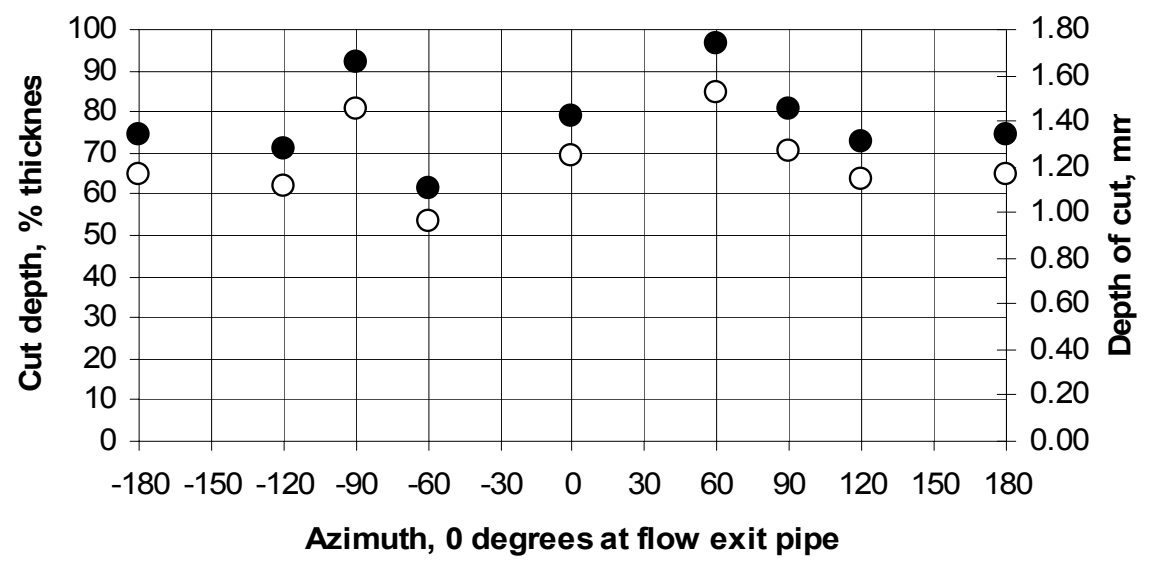

Fig. 10. The variation in depth of trough is shown, as a function of angle (counterclockwise) from the point of the anode closest to the exit flow pipe. Solid points indicate percentage of thickness. The non-uniform cut is attributed to the partial detachment of cathode insulation and the blockage of parts of the metal plate.

\section{Rotating Cathode with Full Perforation}

The following changes in parameters were made: (1) increased electrolyte concentration to $0.4 \mathrm{~kg} / \mathrm{kg}$-water, (2) added pressure gauges on the inlet and exit of the cell, and (3) lowered the applied current from 50 to $25 \mathrm{~A}$. The modifications to electrolyte concentration and applied current were intended to improve efficiency of the anodic dissolution process by improving mass transport capability. A second objective was to lower cell voltage and power at a fixed total current. We weighed the work piece to determine the amount of steel removed, and compared it with predictions from measurements of charge-passed.

The efficiency was quite high - an average efficiency of $74 \%$ for equal times spent at $25 \mathrm{~A}$ and $50 \mathrm{~A}$ rates. However, the lacquer insulation again detached from the surface of the cathode, leading to stray cutting and less than the expected $100 \%$ efficiency. Because of the unexpectedly wide channel cut $(0.24 \mathrm{~cm})$ the time to cut was long $(30 \mathrm{~min})$. The cut plate is shown in Fig. 11. The dependence of cell voltage (and power) on current (Fig. 12) indicate that currents as high as $100 \mathrm{~A}$ might be applied to the cell without loss of voltage stability. Such high current will proportionately increase the rate of cutting of the steel plate. 


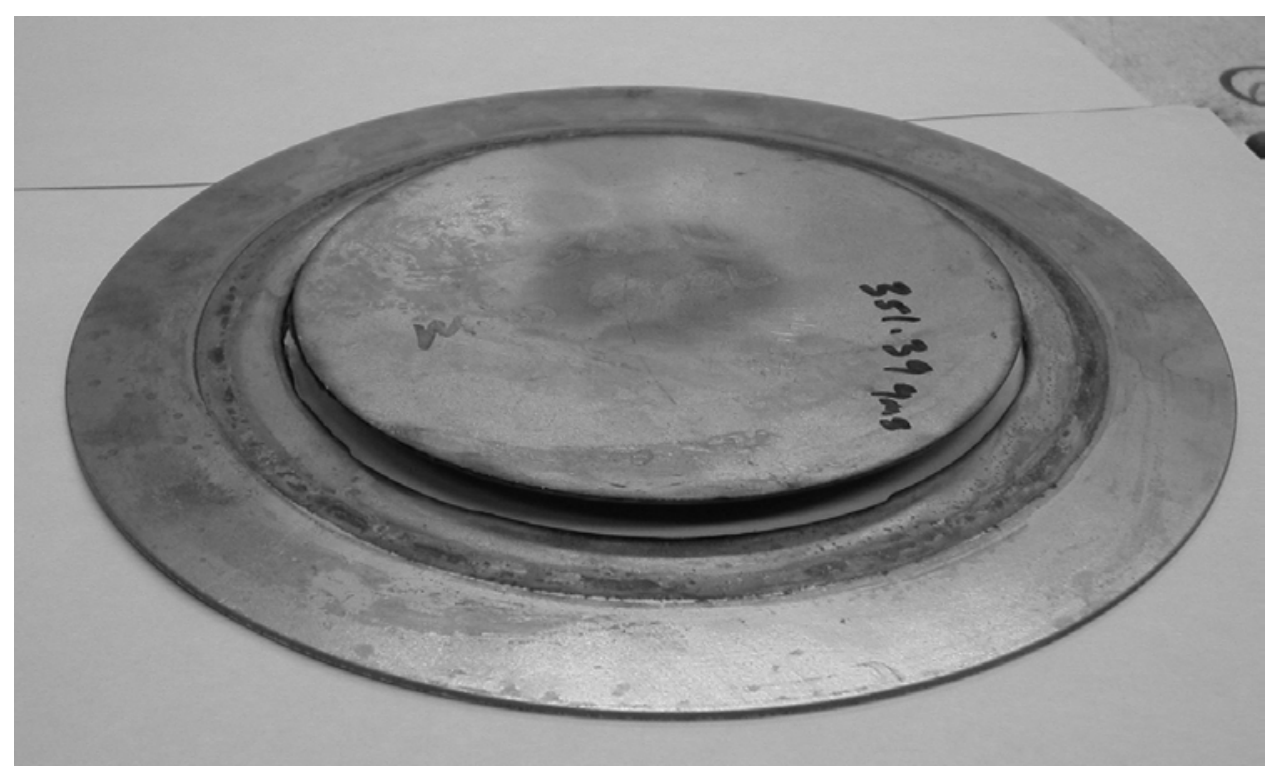

Fig. 11. Through cut with rotating cathode; average width of cut was $0.24 \mathrm{~cm}(0.1 \mathrm{inch})$; diameter was $13 \mathrm{~cm}(5.1 \mathrm{inch})$. Mass of iron removed in cut was $11.72 \mathrm{~g}$.

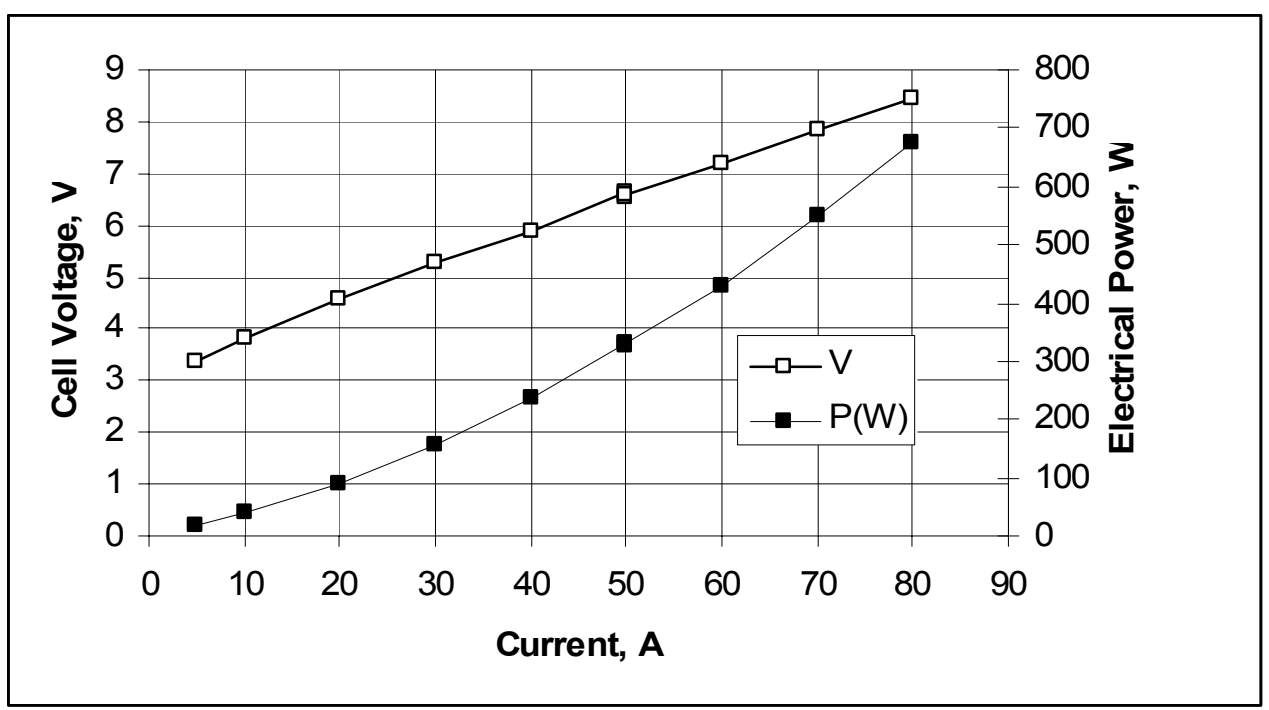

Fig. 12. This shows the dependence of cell voltage and electrical power on the applied current, at a point near to full through cut of the $0.15 \mathrm{~cm}$ thick mild steel plate.

\section{Rotating Cathode, Full Perforation and Increased Efficiency}

Next, we increased efficiency of the process by increasing concentration of the electrolyte to $0.6 \mathrm{~kg} \mathrm{NaClO} / 3 \mathrm{~kg}$-water and operated with electrolyte temperature at 40-45 ${ }^{\circ} \mathrm{C}$. This allowed current levels to be raised to $100 \mathrm{~A}$ without encountering any instability of the voltage or any spark discharge through the gas films on the cathode. The cell voltages remained at 8-10 V, which decreased towards the end of the run. A full 
perforation of the plate was achieved after roughly 11 minutes. A photograph of the perforated plate is shown in Fig. 13.

The efficiency is still lower than achievable in the current configuration for three reasons: (1) The electrolyte concentration can be increased further to $600 \mathrm{~g}-\mathrm{NaClO}_{3} / \mathrm{liter}$ solution $(5.6 \mathrm{M})$, increasing conductivity and lowering voltage. (2) A more adherent insulation may be applied to the cathode (i.e., anodized aluminum cladding), reducing the scattering of current that follows detachment of the lacquer insulation. (3) Current levels can be increased to between 100 - and $200 \mathrm{~A}$.

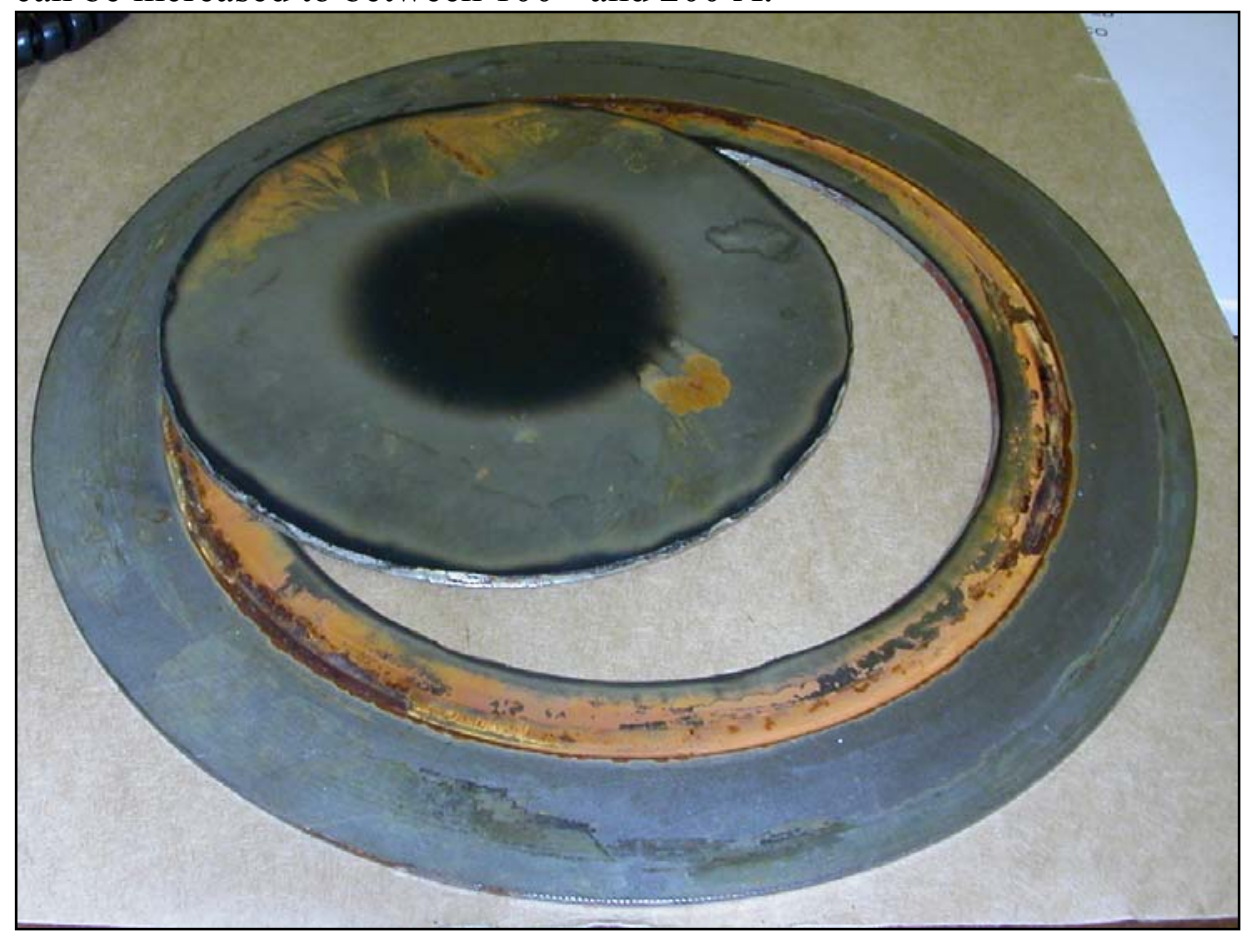

Fig.13. The $1.5 \mathrm{~mm}$ plate was fully perforated in 11 minutes, by ECM alone. To achieve these results, electrolyte concentration was raised to $0.6 \mathrm{~kg} \mathrm{NaClO} / \mathrm{kg}$-water, temperature was allowed to rise to $42.5^{\circ} \mathrm{C}$, and a fixed current of $100 \mathrm{~A}$ was applied to the cell. Pressure drops across the cell were measured at $10 \mathrm{kPa}(1.5$ psi) at flow rates of $0.51 / \mathrm{s}$. A $94 \mathrm{~W}$ centrifugal pump circulated the electrolyte.

\section{Rotating Cathode, Perforation Completed using a Utility Knife; Temperature Profiles}

In the last experiment, we sought to measure any temperature increase within the mild steel anode by placing thermocouples in contact with the anode on the opposite surface. The brass base plate was replaced by a plastic slab $1.9 \mathrm{~cm}$ thick, into which a groove was cut of the diameter of the cathode. Six thermocouples were positioned at regular intervals in contact with the surface of the plate opposite the ECM-cut trough. A hole was drilled into the groove and attached to a drain tube to allow observation of leakage indicating that the anode had been perforated.

Electrolyte concentration was increased to $600-\mathrm{g} \mathrm{NaClO}_{3}$ per liter of solution (5.6 $\mathrm{M})$, having a density of $1.36 \mathrm{~g} / \mathrm{ml}$. The solution was not heated. The cut was made in 3 intervals at a maximum current of $100 \mathrm{~A}$, until perforation was just detected by leakage 
of electrolyte into the trough. Examination of the plate indicated that the leakage was observed through a $0.5 \mathrm{~mm}$ long hole in the base of the anode trough. The current and intervals of application are given in Table 1 along with the measured increase in temperature at one of the thermocouples. The maximum increase in the thermocouple temperature measured at the base of the plate opposite the cut was $20^{\circ} \mathrm{C}$, while the electrolyte registered an increase in temperature of $15^{\circ} \mathrm{C}-$ close to the calculated adiabatic increase in temperature for power dissipation into the bulk electrolyte. These results indicate that trough temperature can exceed bulk temperature by a small amount $\left(5^{\circ} \mathrm{C}\right)$, but the bulk electrolyte temperature is bound within a $15{ }^{\circ} \mathrm{C}$ increase and no temperature spikes were observed. The trough thermocouple trace showing the largest temperature increase is shown in Fig. 14. The experiment was interrupted twice to allow repositioning of the cathode. The traces of each of the six thermocouples (together with two thermocouples in the free flowing electrolyte and one fiduciary thermocouple open to the air) are shown in Appendix A.

Table 1. Increase of temperature measured opposite the trough during perforation of a 1.5 $\mathrm{mm}$ thick mild steel plate; electrolyte mass is $13.6 \mathrm{~kg}$; flow rate is $0.5 \mathrm{l} / \mathrm{s}$.

\begin{tabular}{|c|c|c|c|c|c|}
\hline $\begin{array}{c}\text { Time } \\
\text { interval, } \mathrm{s}\end{array}$ & Current & Voltage & $\begin{array}{c}\text { Final T, } \\
\text { within } \\
\text { interval } \\
{ }^{\circ} \mathrm{C}\end{array}$ & $\begin{array}{c}\text { Solution } \\
\mathrm{T},{ }^{\circ} \mathrm{C}\end{array}$ & $\Delta \mathrm{P}, \mathrm{kPa}$ \\
\hline 0 & 0 & 0 & 23.3 & 23.3 & 0 \\
\hline 120 & 50 & 7 & 25 & & 19.3 \\
\hline 120 & 75 & 9.5 & 26 & & 13.8 \\
\hline 360 & 100 & 10.0 & 38 & & 6.9 \\
\hline 90 & 100 & 10.0 & 39.4 & & 6.9 \\
\hline 150 & 100 & 10.0 & 43.3 & 37.7 & \\
\hline
\end{tabular}

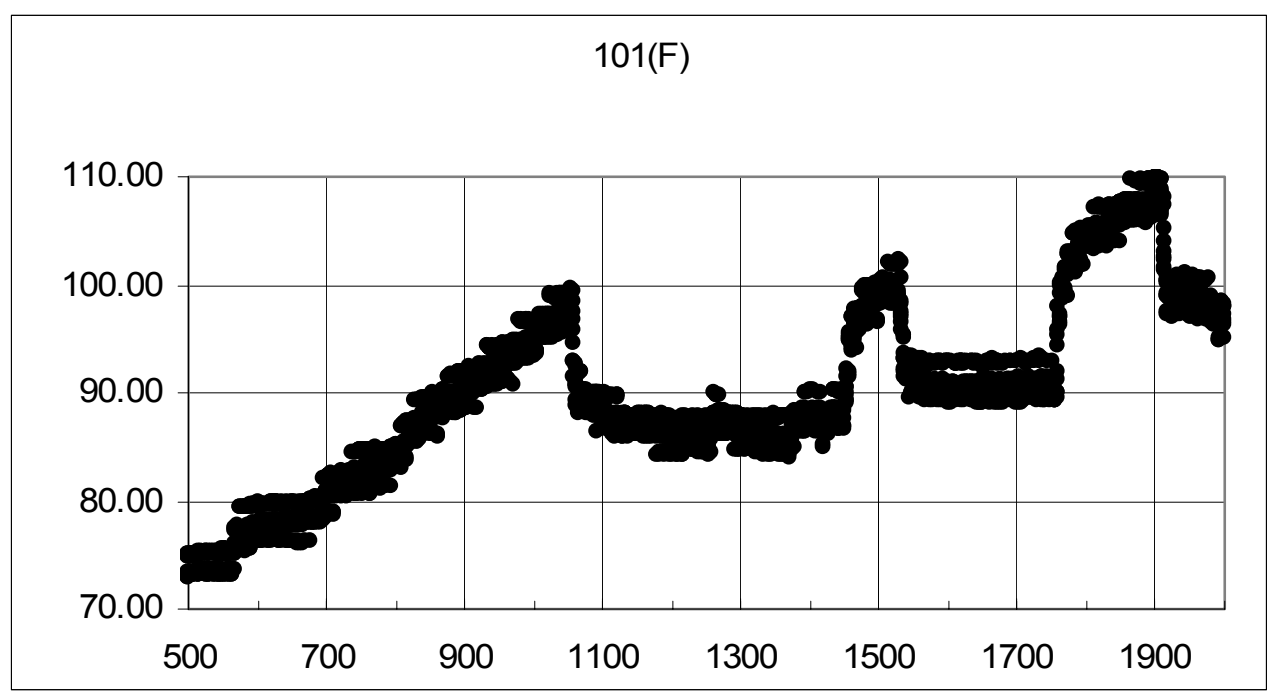

Fig. 14. Sample temperature from point on surface of steel plate opposite the trough made by the ECM cut. Temperature is given in ${ }^{\circ} \mathrm{F}$. A considerable amount of scatter occurred in the thermocouple trace, for causes unrelated to the experimental conditions in the cell. 
The maximum increase in the trough temperature was $35^{\circ} \mathrm{F}\left(19.4^{\circ} \mathrm{C}\right)$, while the bulk electrolyte temperature increased by $15^{\circ} \mathrm{C}$.

A second objective of this test was to show that the electrochemical machining process could be terminated just after initial perforation of the plate, and the remaining thin membrane holding the disk in place could be cut through with a common utility knife. Incipient perforation of the plate was detected by flow of electrolyte into the channel cut to accommodate the thermocouples, and the current flow was immediately interrupted. The plate was removed and the disk freed by cutting through the membrane residual using a common, straight-blade utility knife in less than 1 minute.

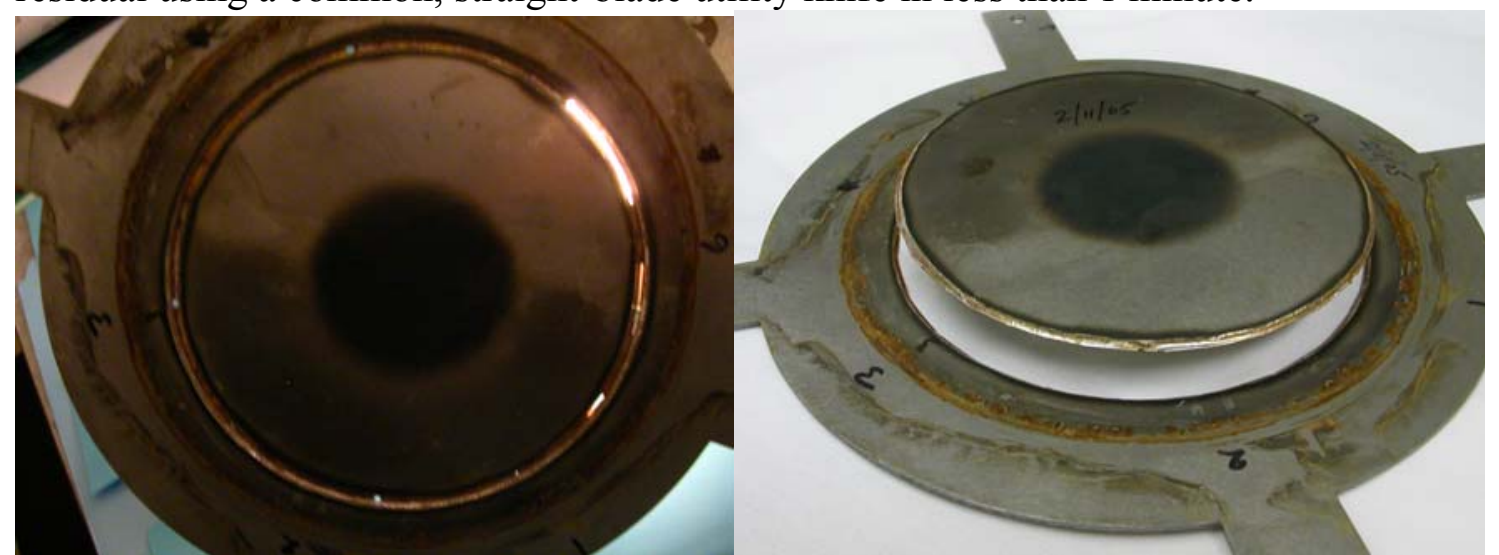

Fig. 15. The plate was cut partially through by ECM leaving a thin membrane between disk and surrounding plate (left). The disk was then freed from the plate (right) using a common straight-blade utility knife in less than 1 minute.

\section{Interpretations of Results}

The reported experiments with ECM support the use of this technique to cut portholes through sheet metal in accordance with goals discussed in the introduction: rapid cutting (less than 10 minutes); silent; vibration free; and safety. The following interpretations are offered:

(1) Optimum conditions. The optimum conditions appear to be (a)a highly concentrated solution at $600 \mathrm{~g}-\mathrm{NaClO}_{3} /$ liter solution $(5.6 \mathrm{M})$; (b) ambient temperature at startup $\left(18-24{ }^{\circ} \mathrm{C}\right)$, with heat retention and temperature rise of about $20^{\circ} \mathrm{C}$, (c) ECM at $100 \mathrm{~A}, 10 \mathrm{~A} / \mathrm{cm}^{2}$, and $10 \mathrm{~V}$; (d) advance of the cathode intermittently during EMC. It should be emphasized that these conditions do not approach the limit of what is possible and has been demonstrated by ECM (i.e., cutting rates a factor of 10-100 times faster; very high solution flow rates and pressure drops). Rather, these "optimum conditions" reflect what is practical for intended applications.

(2) Improve adherence of insulation. The efficiency of the process (and the ability to cut the porthole in less than 10 minutes) suffered greatly because of the failure of adherence of the insulation to the cathode. High efficiency requires that the trough be cut with minimum charge-passsed. This means that the cathode must focus the lines of current flow over a very small area, and that only the active surface of the cathode ring $(0.5 \mathrm{~mm}$ wide by $13 \mathrm{~cm}$ diameter $)$ be exposed to the electrolyte. 
(3) Increase temperature. Working at a temperature of $40-50{ }^{\circ} \mathrm{C}$ will increase conductivity of the electrolyte and lower voltages at fixed current. This will allow applied current to be increased, if desired, to decrease the time for the cut. Higher temperatures will allow still higher rates, but carry the added complexity of electrolyte heaters and enhanced electric power. Preheating of the electrolyte does not appear to be necessary to achieve process goals.

(4) Parallel reactions. In each of the experiments conducted, far more charge was passed than necessary to remove the metal in the trough-evidence that parallel parasitic reactions are consuming electric power without cutting metal. The likely parasitic anode reaction is oxygen evolution. This can be minimized by increase of temperature, increase of electrolyte concentration, increase of flow rate, or decrease of current. If cutting time well below 10 minutes is required, efforts will be needed to curtail the parallel reactions.

(5) Temperature excursions in the trough. The power dissipation $(\mathrm{P})$ of the process (at $10 \mathrm{~V}$ at $100 \mathrm{~A}$ ) increases electrolyte temperature at a rate predicted by heat capacity $\left(\mathrm{C}_{\mathrm{p}}\right)$, density $(\rho)$ and volume flow rate $(\mathrm{G}): \mathrm{dT} / \mathrm{dt}=$ $\mathrm{P} / \mathrm{C}_{\mathrm{p}} \rho \mathrm{G}$. The temperature in the trough leads this rate by about $5^{\circ} \mathrm{C}$, likely due to the dissipation of energy in the surface films formed during transpassive dissolution. This increase is stable and will not lead to a safety problem or a significant thermal excursion. Sparking discharge is not observed here or in ECM processes that take place below about $20 \mathrm{~V}$.

\section{Implementation of the Process}

In a separate document we have proposed engineering development of a prototype. ${ }^{4}$ The prototype will be transportable, weigh less than $100 \mathrm{lbs}$, and be powered by rechargeable batteries (or rectified line current). The device proposed (Figure 16) has the following capabilities.

1. Curved surfaces. The cathode ring will be replaced with a closed loop deformable cathode, using independently positioned insulated pins. This device is similar to a pin contour gauge. The individual pins are made of copper with an anodized aluminum cladding on the vertical surfaces. The deformable cathode will allow cuts to be made through surfaces with irregular curvature in two dimensions.

2. Cathode advance. The cathode will be advanced by rack-and-pinion continuously or after discrete intervals of ECM cutting. The cathode will initially be pressed against the work piece (with current off) so that the cathode shape will conform to the actual curvature of the work piece.

3. Hydrocyclone. The hydrocyclone takes the place of the holding tank and baffles, and allows rapid inline separation of gas and electrolyte.

4. Negative pressure. We will operate with a flow through the cell which is below atmospheric pressure. The first breakthrough of the container will register a slight increase in pressure which will trigger shut down of the flow and drain the cell. This prevents leakage of electrolyte solution into the container.

\footnotetext{
${ }^{4}$ John F. Cooper, Mark Evans and William Siegel, "Plan for demonstrating rapid access system," LLNL proposal, January 26, 2005.
} 
5. Battery power. A number of secondary (rechargeable) batteries are available with the required power $100 \mathrm{~A}$ at $10 \mathrm{~V}$ for 20 minutes (2x excess). In parallel, we will include an option for power by rectified line power.

6. Attachment and grounding of cell. The cell will have flexible elastomer walls to accommodate arbitrarily shaped work pieces, and will be attached using a fast set epoxy; paint will be removed from the work piece to allow current flow. The work piece will be grounded in the immediate vicinity of the cell to prevent stray currents and ground loops.

7. Transportation. The unit will be contained in and transported by a conventional wheeled container or back pack.

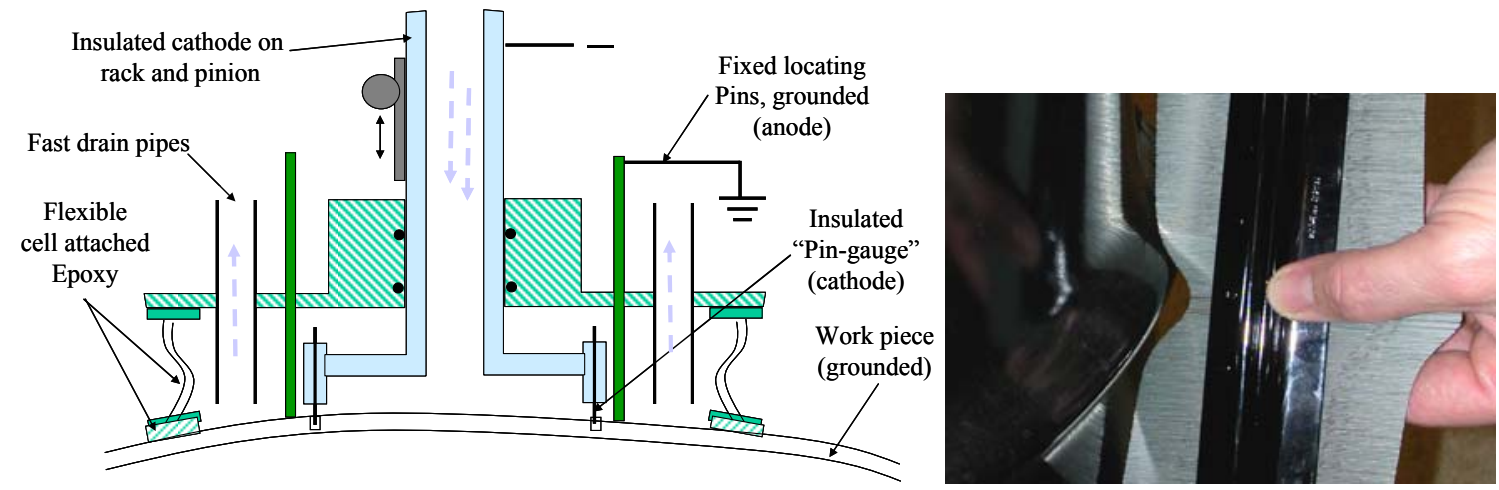

Fig. 16. Proposed system for implementation and cell with deformable cathode similar to pin contour gauge (right).

\section{Conclusions}

This work establishes the feasibility of using electrochemical machining to rapidly cut $13 \mathrm{~cm}$ diameter access holes through sheet steel in a time of 10 minutes or less and without vibrations, noise and excessive heating. The overall mass and volume of the equipment indicate a man-portable scale of operation. The process is safe and hazard free. The system is nearly isothermal, will small excursions of temperature in the trough. The high currents, though a potential hazard, are undetectable if low resistance grounding is provided close to the cathode. The next step is the engineering of a practical prototype.

\section{Acknowledgments}

This work was performed under the auspices of the U.S. Department of Energy by University of California Lawrence Livermore National Laboratory under contract No. W7405-Eng-48. 


\section{Appendix A. Temperature Profiles During Electrochemical Machining}

Temperature traces from the thermocouples attached to the work piece opposite the ECM cut are shown in Figure A1-A6. Figures A7 and A8 show the temperature in the electrolyte at two different points up stream and down stream of the cell. The final trace Figure A9 shows the air temperature, a fiduciary measurement. The scatter is not related to the experimental conditions, and is electronic in origin.

The experimental system is shown in Figure A10. The brass base plate was replaced with an acrylic disk having a circular channel to accommodate the thermocouples. Six thermocouples were placed in the channel and pressed against the steel plate opposite the cutting trough.
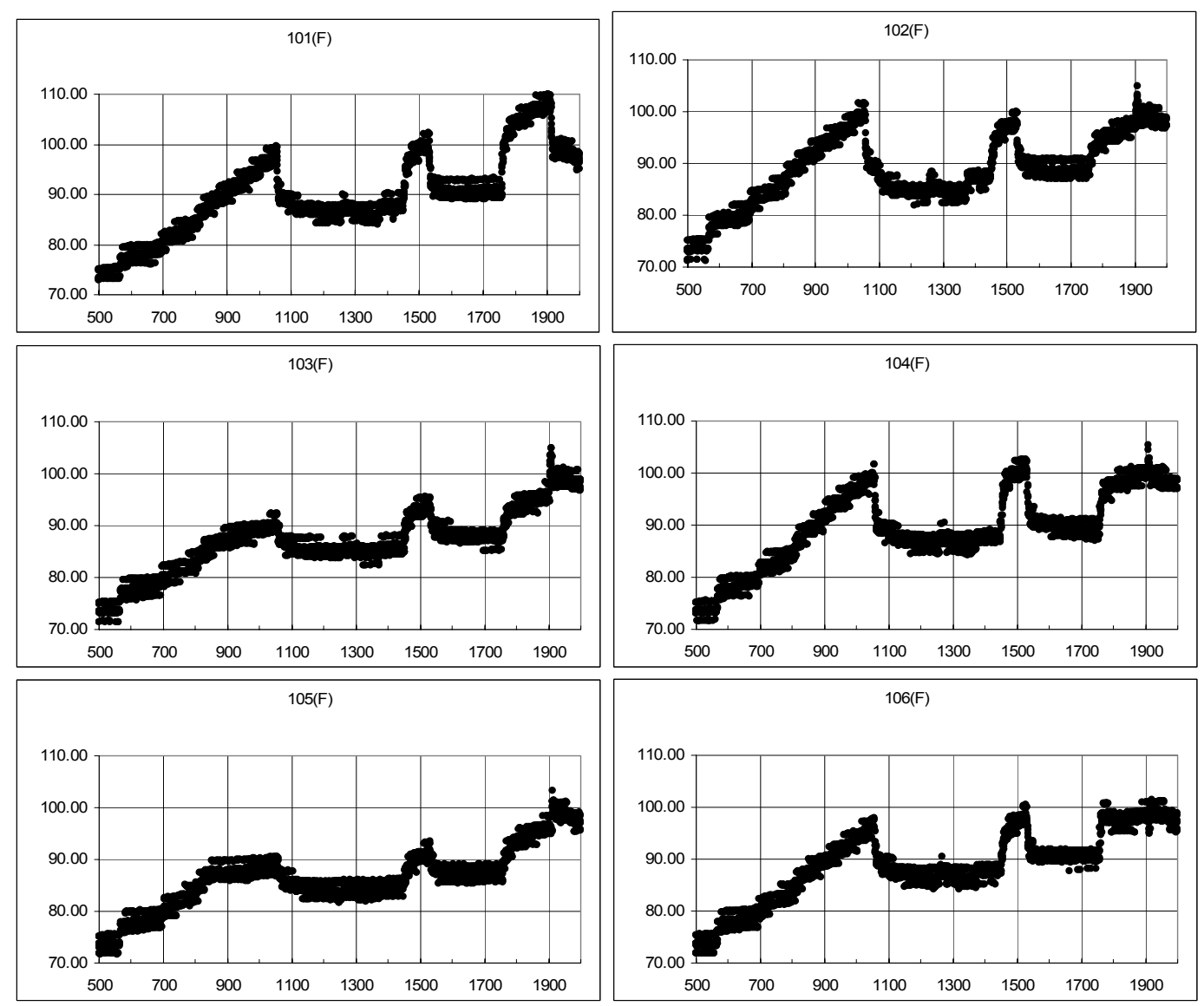

Fig.A1-6. Traces of temperature measured opposite the ECM Cut on the lower surface of the work piece. 

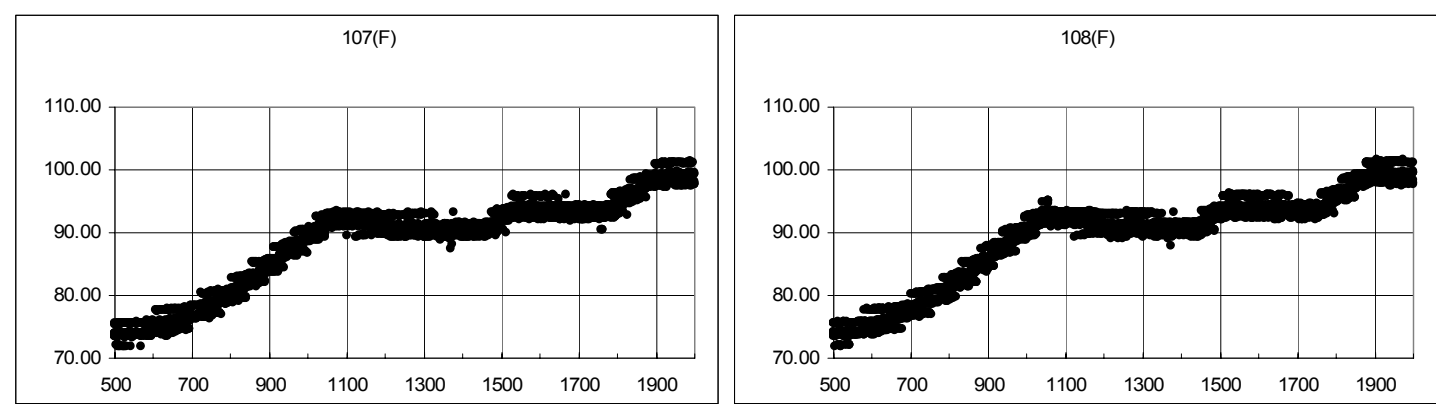

Fig. A7-8. Temperature measured within the electrolyte at two points in the flowing electrolyte solution.

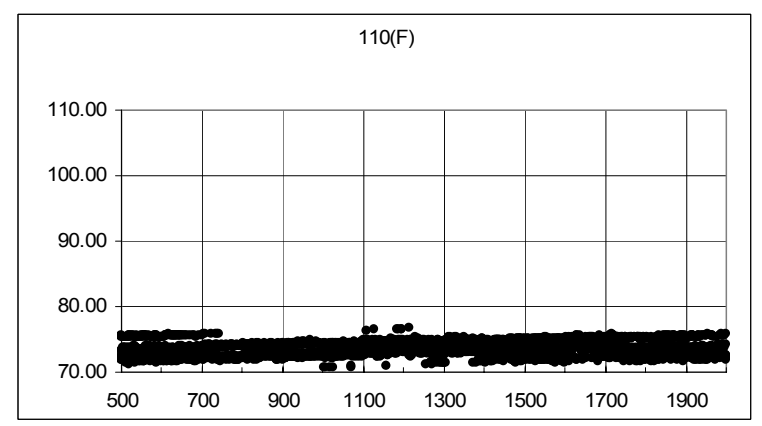

Fig. A9. Measurement of the air temperature outside the cell, a fiduciary temperature measurement, shows the same magnitude of scatter as the thermocouples in the cell. 


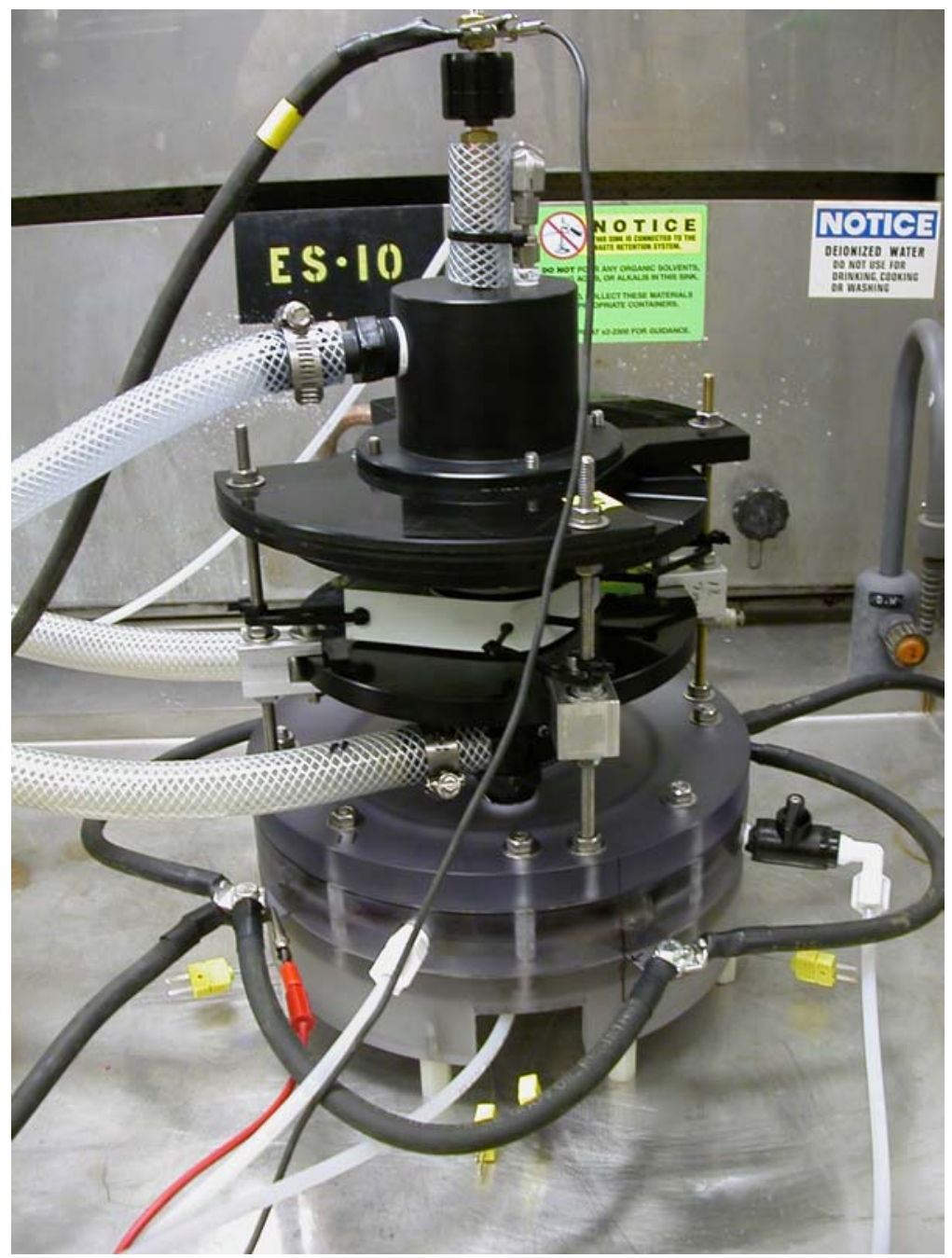

Fig. A10. The experimental cell as modified to accommodate 6 thermocouples in opposite the trough cut by ECM, using a $1.9 \mathrm{~cm}$ thick acrylic plate (in stead of the brass plate, Figure 3 ) to hold the thermocouples and to simulate the heat transfer characteristics of a (hollow) sheet metal container. 